\title{
ATR - FTIR Spectral Analysis of Ferns Using as Fingerprint for Identification of Fern Species
}

\begin{abstract}
CARMEN MIHAELA TOPALA*, ALINA PAUNESCU, LILIANA CRISTINA SOARE
University of Pitesti, Department of Natural Sciences, 1 Targul din Vale Str., 110040, Pitesti, Romania

This study used Attenuated Total Reflection Fourier Transform Infrared (ATR-FTIR) spectroscopy to provided detail information of the organic functional group of secondary metabolites, produced by ferns. The study showed ATR-FTIR spectra of nine fern species: Asplenium scolopendrium, Asplenium trichomanes, Asplenium trichomanes-ramosum, Athyrium filix-femina, Dryopteris affinis, Dryopteris filix-mas, Polypodium vulgare, Polystichum lobatum and Phegopteris connectilis. After comparison of each plant FTIR region divided in three areas: $2800-3000 \mathrm{~cm}^{-1}$ (aliphatic region), $1600-1800 \mathrm{~cm}^{-1}$ (distinct oxygenated groups) and $700-900 \mathrm{~cm}^{-1}$ (aromatic bands). ATR-FTIR Spectroscopy combined with multivariate data analysis have been applied for the discrimination of 9 fern species.
\end{abstract}

Keywords: fern, spores, Asplenium, Dryopteris, Polypodium, Polystichum, Phegopteris, mid-infrared spectroscopy

Attenuated Total Reflectance (ATR) is today the most widely used FTIR sampling tool. ATR generally allows qualitative or quantitative analysis of samples with little or no sample preparation. It is an efficient technique for analyzing functional group of organic substances for identify structure of compounds.

FTIR uses the vibrational characteristics within molecules to obtain a fingerprint spectrum with features defined by the functional chemical groups within the sample. Each biological material presents unique spectrum signals.

Attenuated total reflectance (ATR) spectra of plant leaves display complex absorption features related to organic constituents of leaf surfaces.

Leaves are complex assemblages of organic compounds and it might be expected that they would display distinctive spectral features in the infrared range $\left(4000-400 \mathrm{~cm}^{-1}\right)$. Fundamental vibration modes of various molecular functional groups produce characteristic spectral absorption features that can serve to fingerprint many compounds [1]. Such functional groups and related spectral features include hydroxyl $(\mathrm{OH})$ in alcohols and acids, carbonyl $(\mathrm{C}=0)$ in esters, ketones, aldehydes and acids, and methyl $\left(\mathrm{CH}_{3}\right)$ and methylene $\left(\mathrm{CH}_{2}\right)$ in alkanes.

Ferns are widespread plants, sometimes found in unique habitats. They contain numerous secondary metabolites of the terpenoid, phenol, flavonoid and alkaloid classes [2]. Some of these metabolites are found only in certain species or in certain tissues of the plant.

The goal of our work was to explore the possibility to use FTIR spectral as fingerprint of fern substances found in each species. Different fern species can be recognized by pattern of FTIR spectra. The information could be kept as reference materials for prompt identification of ferns.

\section{Experimental part}

Materials and methods

Leaves were collected from ferns that grow in the Valsan Valley (August 2018). The nine species of fern are: Asplenium scolopendrium L. (Aspleniaceae) (1), Asplenium trichomanesL. (Aspleniaceae), (2) Asplenium trichomanes-ramosum L. (Aspleniaceae) (3), Athyrium filix-femina (L.) Roth. (Woodsiaceae) (4), Dryopteris affinis (Dryopteridaceae) (5), Dryopteris filix-mas
(Dryopteridaceae) (6), Polypodium vulgare L. (Polypodiaceae) (7), Polystichum aculeatum (L.) Roth (Dryopteridaceae) (8) and Phegopteris connectilis (Minchx) Watt (Thelypteridaceae) (9) [3]. The leaves were dried at room temperature.

Spores collected from four species of ferns $(\mathbf{1}, \mathbf{4}, \mathbf{5}$ and 9) were analyzed. The spores were stored both at room temperature $\left(1^{\prime}, 2^{\prime} 3^{\prime}, 9^{\prime}\right)$ and refrigerated at $4^{\circ} \mathrm{C}\left(\mathbf{1}^{\prime \prime}, \mathbf{2}^{\prime \prime}\right.$, 3") [4].

The spectral measurements were made with a FTIR Jasco 6300 spectrometer. An ATR accessory equipped with a diamond crystal (Pike Technologies) allows collection of FTIR spectra directly on a sample without any special preparation. The spectra were recorded in the region of 4000-400 $\mathrm{cm}^{-1}$, detector TGS, apodization Cosine. The spectral data were processed with JASCO Spectra Manager II software. Samples were scanned at $4 \mathrm{~cm}^{-1}$ resolution, accumulation: 100 scans. IR bands were identified by comparison with published assignments [5-7].

FTIR spectra show differences in functional-group abundances, even when spectra appear similar in terms of peak shape, peak positions, and intensities. How ever, closer analysis of the spectral files can reveal subtle differences that can be important for the interpretation of chemical structure. This involves the calculation of ratios of integrated areas under the IR-absorbance bands for semi-quantitative analysis. The methylene/methyl ratio $\left(\mathrm{CH}_{2} / \mathrm{CH}_{3}\right)$ relates to the aliphatic-chain length of hydrocarbons and to the degree of branching of aliphatic side chains attached to the biomolecular structure. The ratio is calculated after deconvoluting the aliphatic stretching region $\left(2800-3000 \mathrm{~cm}^{-1}\right)$ into individual peaks. A larger ratio implies comparatively longer and straight chains, and a smaller one shorter and more branched chains $[8,9]$.

For statistical analysis, spectra in absorbance were normalized and the 2 nd derivatives of each spectrum were calculated using a Savitzky-Golay algorithm to enhance the resolution of the superimposed bands. The data were imported from FTIR ASCII (dx) into the Unscramble software (Edition X 10.4, Camo. Oslo Norway) for statistical analysis. The fingerprint domain of FTIR spectra has been selected in the statistical processing. The principal component analysis (PCA) model was developed using

*email: carmen.topala@gmail.com; Phone: 0745981621 
cross validation. PCA was performed both on the entire spectral range (4000 to $400 \mathrm{~cm}^{-1}$ ), and on the peak areas corresponding to regions: $700-900 \mathrm{~cm}^{-1} 1600-1750 \mathrm{~cm}^{-1}$ and $2800-300 \mathrm{~cm}^{-1}$.

\section{Results and discussions}

The leaf is covered by the outer single layer epidermis; the walls of the epidermal cells have a complex chemical composition, made up of cellulose, hemicelluloses, pectins, glycoproteins, etc. Cutin impregnates and covers the outer tangential walls of the epidermal cells, forming the cuticle in and on which there is wax.

Leaf surfaces are composed of many organic compounds and produce complex spectra showing many absorption bands. At the present level of understanding it is not possible to identify all of the specific compounds responsible for every spectral feature. However, it is possible to identify major classes of compounds and to recognize whether a particular class is especially abundant in a particular leaf sample [10].

The FTIR spectra of nine species of ferns are shown in figures 1 and preliminary assignments are present in table 1.
The FTIR spectrum of ferns (table 1 ) is characterized by distinct aliphatic bands in the aliphatic stretching region $2800-3000 \mathrm{~cm}^{-1}$ ( fig. 1, table 2), distinct oxygenated groups at $1600-1800 \mathrm{~cm}^{-1}$ (fig. 1, table 2), and three detectable aromatic bands in the out-of-plane region [11]. Distinct oxygenated groups are represented by peaks $\sim 1735 \mathrm{~cm}^{-1}$ and $\sim 1600 \mathrm{~cm}^{-1}$, assigned to esters and conjugated ketones, respectively [12]. A peak at 1509-1518 $\mathrm{cm}^{-1}$ likely represents a benzene ring.

The aliphatic stretching region for all specimens is very similar, with dominant $\mathrm{CH}_{2}$ bands at 2920 and $2851 \mathrm{~cm}^{-1}$ and a shoulder of $\mathrm{CH}_{3}$ at $2951 \mathrm{~cm}^{-1}$ ( fig. 1). Because of this similarity, the $\mathrm{CH}_{2} / \mathrm{CH}_{3}$ ratio ranges only from 2.76 to 3.31 . For species $\mathbf{1}, \mathbf{3}$ and $\mathbf{5}$ methylene/methyl ratio $\left(\mathrm{CH}_{2} / \mathrm{CH}_{3}\right)$ is something smaller than the other species. Asplenium trichomanes (2) and Polypodium vulgare (7) have a broad peak at $1600 \mathrm{~cm}^{-1}$. Some differences amongst the specimens of ferns are detected in the region of 1200 $1500 \mathrm{~cm}^{-1}$ (table 1). For Dryopteris affinis (5), Dryopteris filix-mas (6) similar peaks appear for $\mathrm{C}-\mathrm{O}$ stretching at $1240 \mathrm{~cm}^{-1}$, while for Polypodium vulgare (7), Polystichum

Table 1

THE PRELIMINARY ASSIGNMENT OF THE FERN SPECIES

\begin{tabular}{|c|c|c|c|c|c|c|c|c|c|}
\hline \multicolumn{9}{|c|}{ Frequencies $\left[\mathrm{cm}^{-1}\right]$} & \multirow[b]{2}{*}{ Assignment } \\
\hline 1 & 2 & 3 & 4 & 5 & 6 & 7 & 8 & 9 & \\
\hline 3268.75 & 3269.72 & 3274.54 & 3270.68 & 3278.39 & 3279.36 & 3269.72 & 3265.86 & 3262.97 & $\mathrm{v}(\mathrm{O}-\mathrm{H}, \mathrm{N}-\mathrm{H})$ \\
\hline 2917.77 & 2918.73 & 2918.73 & 2918.73 & 2918.73 & 2918.73 & 2917.77 & 2917.77 & 2918.73 & $v_{u r}(C-H)$ \\
\hline 2850.27 & 2850.27 & 2850.27 & 2849.31 & 2850.27 & 2850.27 & 2849.31 & 2849.31 & 2850.27 & $v_{2}(C-H)$ \\
\hline 1735.62 & 1734.66 & 1736.58 & 1733.69 & 1735.62 & 1735.62 & 1734.66 & 1735.62 & 1734.66 & $v-\mathrm{COOH}$ or $v-\mathrm{C}=\mathrm{O}$ \\
\hline 1600.63 & 1600.63 & 1604.48 & 1601.59 & 1604.48 & 1594.84 & 1602.56 & 1597.73 & 1601.59 & $v(\mathrm{C}=\mathrm{O})$ \\
\hline- & 1515.78 & 1509.99 & 1516.74 & 1515.78 & 1518.67 & 1517.70 & 1512.88 & 1514.81 & $\begin{array}{l}\mathrm{v}(C=C-C) \text { aromatic ring } \\
\text { stretch }\end{array}$ \\
\hline 1413.57 & 1415.49 & 1412.60 & 1433.82 & 1417.42 & 1412.6 & 1416.46 & 1415.49 & 1417.42 & $\mathrm{CH}_{2}$ asymmetric bending \\
\hline 1369.21 & 1371.14 & 1370.18 & 1370.18 & 1369.21 & 1372.1 & 1372.1 & 1370.18 & 1361.50 & $\mathrm{CH}_{2}$ bending \\
\hline 1241.93 & 1237.11 & 1235.18 & 1226.50 & 1240.97 & 1240.00 & 1239.04 & 1260.25 & 1233.25 & C-O stretching \\
\hline 1141.65 & 1145.51 & - & - & 1144.55 & 1146.47 & 1144.55 & 1152.26 & - & $\begin{array}{l}\mathrm{O}-\mathrm{C}-\mathrm{O} \\
\text { stretching asymmetric }\end{array}$ \\
\hline 1016.30 & 1013.41 & 1018.23 & 1046.19 & 1014.37 & 1012.45 & 1008.59 & 1017.27 & 1022.09 & $v(=\mathrm{C}-\mathrm{O}-\mathrm{C}), v(\mathrm{C}-\mathrm{C})$ \\
\hline
\end{tabular}
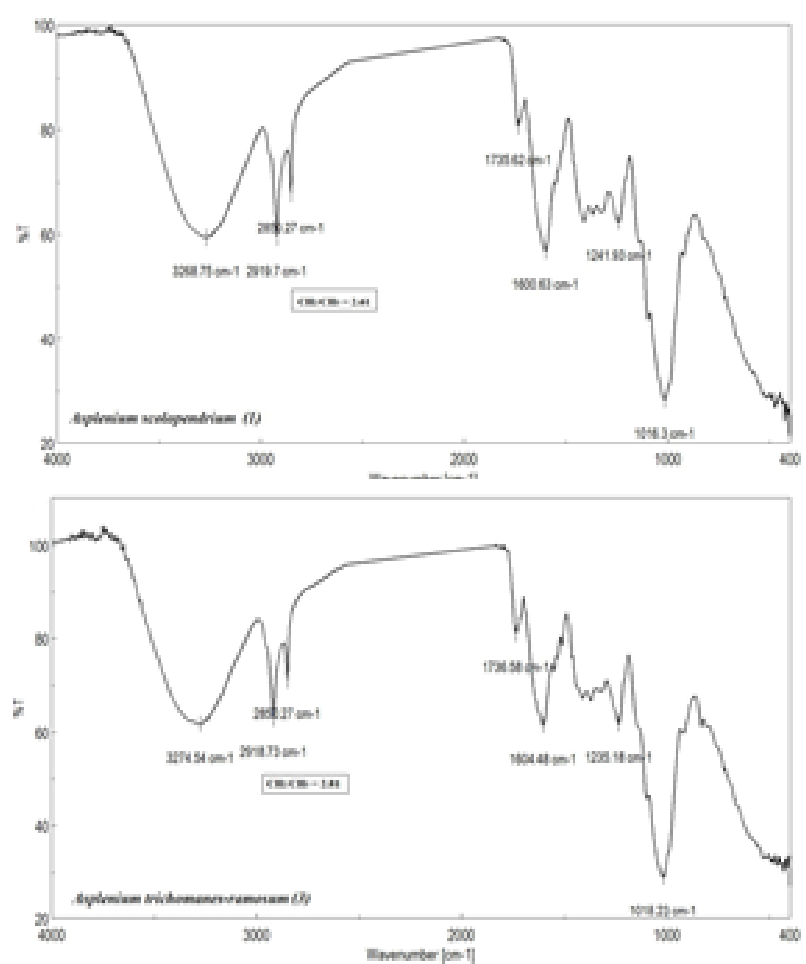
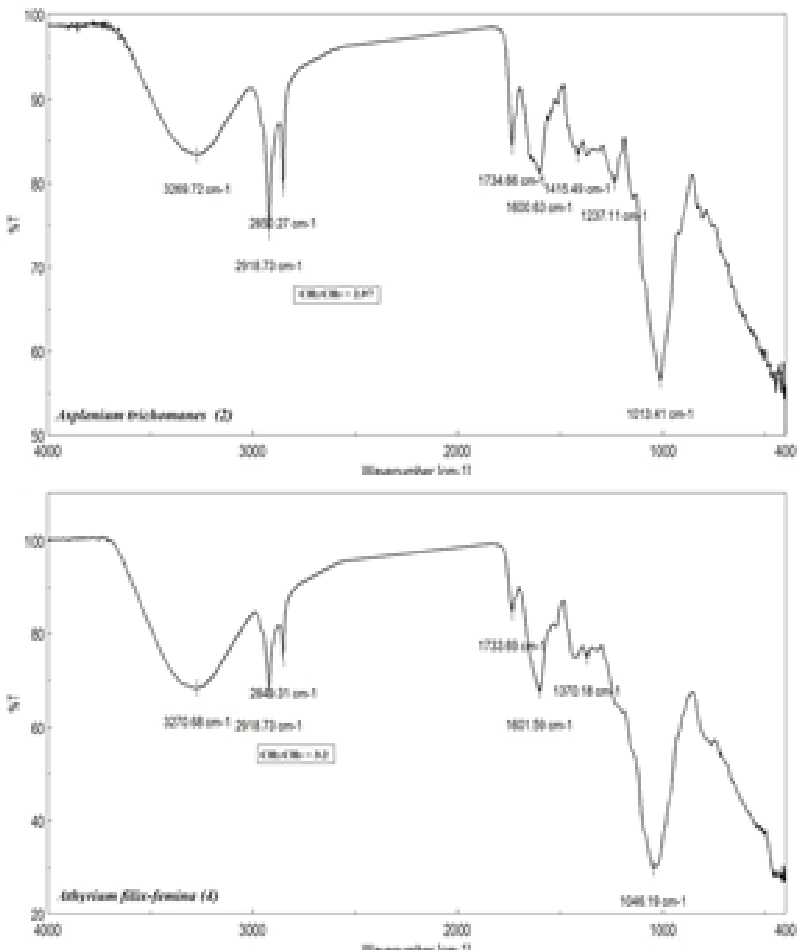

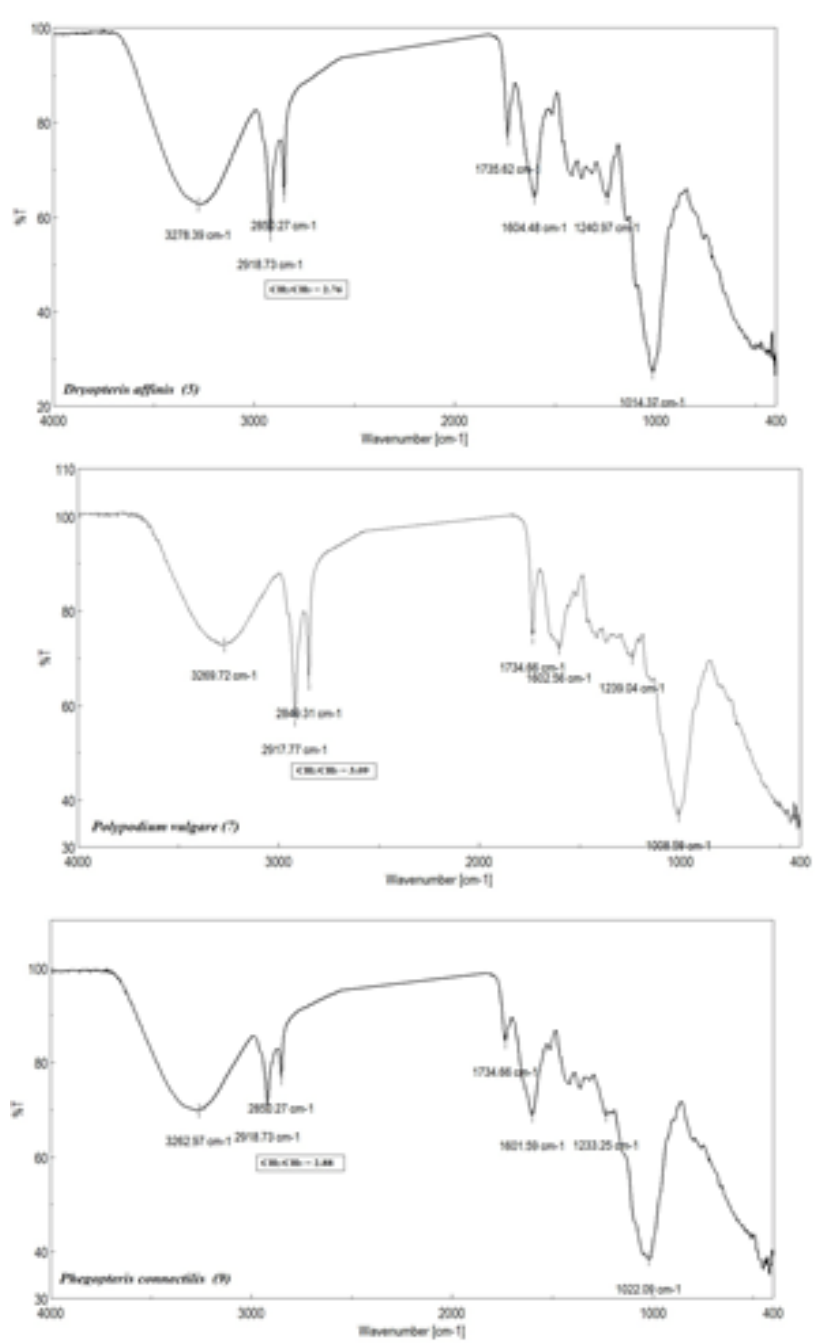

Table 2

SELECTED FTIR DATA OF THE FERNS (LEAVES)

\begin{tabular}{|l|l|l|l|l|}
\hline Species & No sample & $\mathrm{CH}_{2} / \mathrm{CH}_{3}$ & $1600-1800 \mathrm{~cm}^{-1}$ & $700-900 \mathrm{~cm}^{-1}$ \\
\hline Asplenium scolopendrium & $\mathbf{1}$ & 2.61 & $\begin{array}{l}1735.62 \text { distinct } \\
1600.63 \text { proeminent }\end{array}$ & 828.27 \\
\hline Asplenium trichomanes & $\mathbf{2}$ & 2.97 & $\begin{array}{l}1734.66 \text { distinct } \\
1600.63 \text { proeminent }\end{array}$ & $828.27,806.09,763.67$ \\
\hline $\begin{array}{l}\text { Asplenium trichomanes- } \\
\text { ramosum }\end{array}$ & $\mathbf{3}$ & 2.81 & $\begin{array}{l}1736.56 \text { distinct } \\
1604.48 \text { proeminent }\end{array}$ & $833.09,804.17,755.95$ \\
\hline Athyrium filix-femina & $\mathbf{4}$ & 3.02 & $\begin{array}{l}1733.69 \text { distinct } \\
1601.59 \text { proeminent }\end{array}$ & 761.74 \\
\hline Dryopteris affinis & $\mathbf{5}$ & 2.76 & $\begin{array}{l}1735.62 \text { distinct } \\
1604.48 \text { proeminent }\end{array}$ & $811.88,761.74$ \\
\hline Dryopteris filix-mas & $\mathbf{6}$ & 2.95 & $\begin{array}{l}1735.62 \text { distinct } \\
1594.84 \text { proeminent }\end{array}$ & $804.17,764.62$ \\
\hline Polypodium vulgare & $\mathbf{7}$ & 3.09 & $\begin{array}{l}1734.66 \text { distinct } \\
1602.56 \text { proeminent }\end{array}$ & $806.09,762.70$ \\
\hline Polystichum lobatum & $\mathbf{8}$ & 3.12 & $\begin{array}{l}1735.62 \text { distinct } \\
1597.73 \text { proeminent }\end{array}$ & $808.99,760.78$ \\
\hline Phegopteris connectilis & $\mathbf{9}$ & 2.88 & $\begin{array}{l}1734.66 \text { distinct } \\
1601.59 \text { proeminent }\end{array}$ & $798.38,759.81$ \\
\hline
\end{tabular}

aculeatum (8) appear two peaks at 1260 and 1237, 1239 $\mathrm{cm}^{-1}$ respectively.

Table 3 presents the three selected regions for spores of ferns. The outer surface of fern spores is the sporoderm, which consists of the perispore, exospore and endospore. The exospore and the perispore are composed of sporopollenin and other materials and the endospore is of
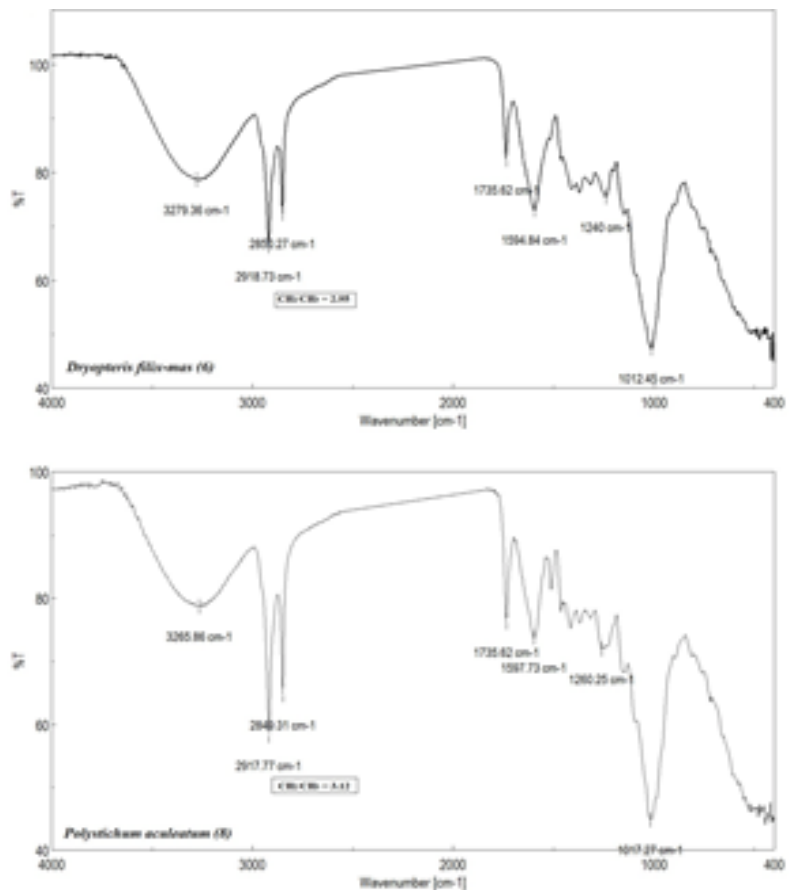

Fig. 1. ATR-FTIR spectra of ferns 1-9 a pectocellulosic nature [13]. The spores contain reserve substances of the lipid and protein groups [14].

A difference between spores and leaves is a higher ratio of $\mathrm{CH}_{2}$ to $\mathrm{CH}_{3}$ for the spores. These observations suggest slightly higher aromaticity for the leaves, perhaps related to some chemotaxonomic differences. IR spectra also suggest that aromatic components are removed from spores during storage. 
Table 3

SELECTED FTIR DATA OF THE SPORES

\begin{tabular}{|l|l|l|l|l|}
\hline Species & No sample & $\mathrm{CH}_{2} / \mathrm{CH}_{3}$ & $1600-1800 \mathrm{~cm}^{-1}$ & $700-900 \mathrm{~cm}^{-1}$ \\
\hline Asplenium scolopendrium & $\mathbf{1}$ & 3.4 & $\begin{array}{l}1743.33 \text { distinct } \\
1600.63 \text { proeminent }\end{array}$ & aromatic bands - traces \\
\cline { 2 - 5 } & $\mathbf{1}$ & 3.53 & 1744.30 distinct & aromatic bands - traces \\
\hline Athyrium filix-femina & $\mathbf{4}$ & 3.20 & $\begin{array}{l}1742.37 \text { distinct } \\
1606.41 \text { proeminent }\end{array}$ & $802.24,766.56$ \\
\cline { 2 - 5 } & $\mathbf{4}$, & 3.37 & $\begin{array}{l}1743.33 \text { distinct } \\
1603.52 \text { proeminent }\end{array}$ & $849.49,810.92,763.37$ \\
\hline Dryopteris affinis & $\mathbf{5}$ & 3.71 & 1739.48 distinct & $850.45,809.95,770.42$ \\
\cline { 2 - 5 } & $\mathbf{5}$ & 3.59 & 1743.33 distinct & $850.45,808.02$ \\
\hline Phegopteris connectilis & $\mathbf{9}$ & 3.45 & $\begin{array}{l}1736.58 \text { distinct } \\
1602.56 \text { proeminent }\end{array}$ & $850.45,810.92,779.10$ \\
\hline
\end{tabular}

The chemometric analysis. Principal Component Analysis (PCA)

All spectra were characterised by a similar profile. No visual differences were observed between the MIR spectra of fern samples analysed. Chemometric analysis allow the differentiation of ferns.

The Principal Component Analysis (PCA) is a well established analysis technique which works by finding the correlation between a set of variables and then creating a new set of uncorrelated variables named principal components (PCs). The spectral reproducibility is important for creating a robust classification model. Generally, the use of spectra derivatives with Savitky-Golay algorithm as a chemometric pre-processing technique is widely reported in most classification based on FTIR spectroscopy [15]. The region from 1765 to $4000 \mathrm{~cm}^{-1}$ was not included in the analysis due to interference from the diamond ATR crystal and remaining water in the samples. For the selected regions (aromatic bands, oxygenated groups and aromatic bands): $700-900 \mathrm{~cm}^{-1} 1600-1750 \mathrm{~cm}^{-1}$ and 2800 $300 \mathrm{~cm}^{-1}$, the results of PCA analysis are presents in figures $2-5$.

Examining the space defined by the first and second PCs as shown in figure 2, samples tend to group themselves in two separate areas/groups. From the selected regions mentioned above the species Asplenium scolopendrium
(1), Asplenium trichomanes-ramosum (3) and Dryopteris affinis (5) are separated from the rest of the ferns, they are located on the right of the graph (fig. 2), which indicates the possibility of separation at genus level. This result confirms the smaller $\mathrm{CH}_{2} / \mathrm{CH}_{3}$ ratio for species $\mathbf{1 , 3}$ and $\mathbf{5}$, calculated after deconvoluting of the aliphatic stretching region $\left(2800-3000 \mathrm{~cm}^{-1}\right)$. The first three principal components (PCS) represent $87 \%$ of the total variance (PC1 $=58 \%, P C 2=26 \%$ and $P C 3=3 \%)$. The differences might be determined by certain secondary metabolites synthesized in the leaves of the tested species, such as the ecdysteroids [16], which are molecules with an important role in the defense against insects [17].

For the ferns 1, 4 and 5, their spores (S1, S4, S5 and refrigerated $\mathrm{Sf1}, \mathrm{Sf4}, \mathrm{Sf5})$ the first three principal components (PCs) represent $98 \%$ of the total variance (PC1 $=71 \%, \mathrm{PC2}=24 \%$ and $\mathrm{PC} 3=3 \%$ ). This indicates that these three components were sufficient to provide a clear separation between the groups.

In figure 3, the spores (in the right of the graph) are separated from their ferns, as a result of the content of different biochemical components [14]. This result confirms the higher $\mathrm{CH}_{2} / \mathrm{CH}_{3}$ ratio for spores (table 3) compared to the ferns (table 2) calculated after deconvoluting of the aliphatic stretching region (2800-3000 $\mathrm{cm}^{-1}$ ).

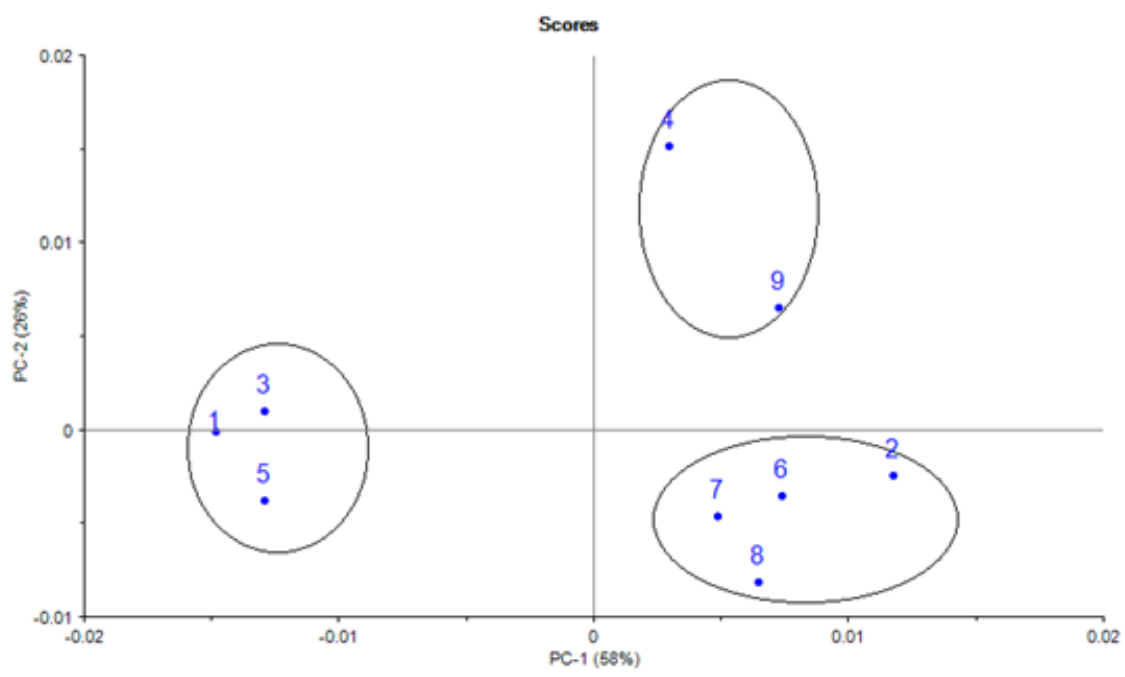

Fig. 2. 2-D scores obtained from PCA of FTIR spectra of ferns 1-8 for the first two PCs based on the FTIR regions: $700-900 \mathrm{~cm}^{-1}$ $1600-1750 \mathrm{~cm}^{-1}$ and $2800-300 \mathrm{~cm}^{-1}$ 

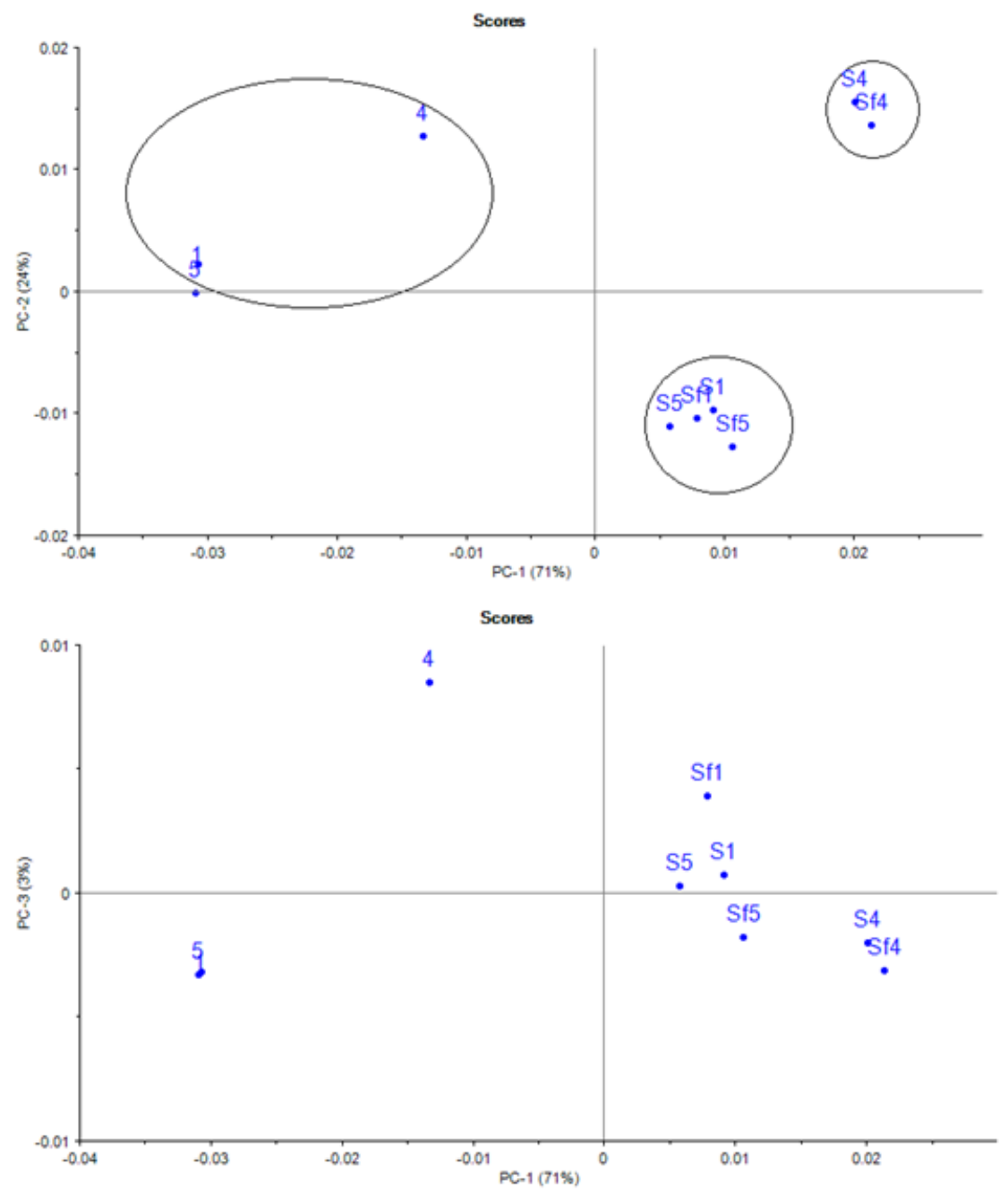

Fig. 3. 2-D scores obtained from PCA of FTIR spectra of ferns (1, $\mathbf{4}$ and $\mathbf{5})$ and their spores (S1, S4 and S5, Sf1, Sf4 and Sf5) for the first two PCs a), and PC3 versus PC1 b) the ferns and spores

\section{Conclusions}

ATR-FTIR spectra coupled with chemometric analyzes can be efficiently used to discrimination fern species.

The use of chemometrics tools for evaluation of fingerprints reduced expense and analysis time. The proposed method can be adopted for routine discrimination and evaluation of the phytochemical variability in different fern species. Each species of fern produces difference secondary metabolic products, which are used as the main criteria for taxonomic identification of fern. This technique is less complicated and economically wise than TLC, HPLC or LC-MS, which are generally used in chemotaxonomy of fern. It will be developed to simplify chemotaxonomy of fern in the future.

Fern spores have a reduced viability, but different conservation methods can extend it. We recommend further research for establish whether the loss of certain compounds during the conservation period affects their viability.

Acknowledgement: This work was supported by a grant of the Romanian Ministery of Research and Innovation, CCCDI-UEFISCDI, project number PN-III-P1-1.2-PCCDI-2017-0332"/Project 3, contract 6PCCDI/2018, within PNCDI III.

\section{References}

1.SILVERSTEIN, R.M, WEBSTER, F.X., Spectrometric identification of organic compounds, 6th edn. New York, NY, USA: John Wiley \& Sons, 1998, p.71-143.
2.HO, R., TEAI, T., BIANCHINI, J .P., LAFONT, R., RAHARIVELOMANANA, P., Ferns: from traditional uses to pharmaceutical development, chemical identification of active principles. In: Working with Ferns: Issues and Applications, eds. H. Fernandez, A. Kumar, M.A. Revilla, Springer, 2011, p.321-346.

3.TUTIN, T.G., BURGES, N.A., CHATER, A.O., EDMONSON, J.R., HEYWOOD, V.H., MOORE, D.M., VALENTINE, D.H., WALTERS, S.M., WEBB, D.A.. Flora Europaea. 2nd ed. Vol. 1. Psilotaceae to Platanaceae. Cambridge: Cambridge University Press, 1993 p.581.

4.SOARE, L.C., ALDOIU, E.N., Research concerning the conservation of the spores of some pteridophytes species. Acta Horti Botanici Bucurestiensis, 37, 2010, p.71-76.

5.PAINTER, P.C., SNYDER, R.M., STARSINIC, M., COLEMAN, M.M., KUEHN, D.W., DAVIS, A., Concerning the application of FTIR to the study of coal: a critical assessment of band assignments and the allocation of spectral analysis programs. Applied Spectroscopy, 35, 1981, p.475-485

6.WANG, S.H., GRIFFITH, P.R., Resolution enhancement of reflectance IR spectra of coals by Fourier-self-deconvolution: 1. C-H stretching and bending modes. Fuel, 64. 1985, p.229-236.

7.SOBKOWIAK, M., PAINTER, P., Determination of the aliphatic and aromatic $\mathrm{CH}$ contents of coals by FT-IR studies of coal extracts. Fuel, 71, 1992, 1105-1125.

8.MASTALERZ, M. and BUSTIN, R.M., Variation in maceral chemistry within and between coals of varying rank: an electron microprobe and micro-FTIR investigation, J ournal of Microscopy 171, 1993, p.153166. 
9.D'ANGELO, J.A., Analysis by Fourier transform infrared spectroscopy of Johnstonia (Corystospermales, Corystospermaceae) cuticles and compressions from the Triassic of Cacheuta, Mendoza, Argentina., Ameghiniana, 43(4), 2006, p.669-685.

10.RIBEIRO da LUZ, B., Attenuated total reflectance spectroscopy of plant leaves: A tool for ecological and botanical studies, New Phytologist, 172, 2006, p.305-318.

11.ZODROW, E.L., MASTALERZ, M., FTIR and py-GC-MS spectra of true-fern and seed-fern sphenopterids (Sydney Coalfield, Nova Scotia, Canada, Pennsylvanian), International Journal of Coal Geology, 51, 2002, p.111 - 127.

12.PRADIER, B., LANDAIS, P., ROCHDI, A. AND DAVIS, A., Chemical basis of fluorescence alteration of crude oil and kerogen: 2 . Fluorescence and infrared micro-spectrometric analysis of vitrinite and liptinide. Organic Geochemistry, 18, 1992, p.241-249.
13.TRYON A.F., LUGARDON B., Spores of the Pteridophyta. Surface, Wall Structure and Diversity Based on Electron Microscope Studies. Springer-Verlag New York Inc, 1991.

14.RAGHAVAN, V., Cytology, physiology, and biochemistry of fern spore germination. Int. Rev. Cytol., 62, 1980, p.69-118.

15.TOPALA, C.M., TATARU, L.D, Rapid Method for the Discrimination of Romanian Wines Based on Mid-Infrared Spectroscopy and Chemometrics, Rev. Chim. (Bucharest), 69, no. 2, 2018, p.469

16.LAFONT, R., HO, R., RAHARIVELOMANANA, P., DINAN, L., Ecdysteroids In Ferns: Distribution, Diversity, Biosynthesis, and Functions In: Working with Ferns: Issues and Applications, eds. $\mathrm{H}$. Fernández, A. Kumar, M.A. Revilla, Springer, 2011 p.305-319. 17.DINAN, L., Phytoecdysteroids: biological aspects, Phytochemistry, 57, 2001, p.325-339.

Manuscript received: 24.08 .2018 